\title{
A Case Study of qs.Al-ikhlas and qs.Al-bayyinah Tafseer Delivered by Nouman Ali Khan (A Pragmatics Approach)
}

\author{
Ayu Nur Azizah \\ Sekolah Menengah Pertama Sains Tebuireng \\ nurazizah.ayu27@gmail.com \\ Irta Fitriana \\ Universitas of Pesantren Tinggi Darul Ulum Jombang \\ irtafitriana@fbs.unipdu.ac.id
}

\begin{abstract}
This is a study of requests strategies delivered by Nouman Ali Khan in Quran tafseer lectures of Qs.Al-Ikhlas and Qs.Al-Bayyinah using Blum-Kulka Theory. This study applied pragmatic approach to analyze the type and the application of request strategies. The aims of this study are; (1) to identify the types of request that are used by Nouman Ali Khan lectures entitled "Qur'an Tafseer of Qs. Al Ikhlas"and "Qur'an Tafseer of Qs. Al Bayyinah" and (2) to explain the application of request used by Nouman Ali Khan lectures entitled "Qur'an Tafseer of Qs. Al Ikhlas"and" Qur'an Tafseer of Qs. Al Bayyinah". This research employed descriptive qualitative method. The data of this study were the utterances taken from the transcript of Quran tafseer lectures of Qs.Al-Ikhlas and Qs.Al-Bayyinah uttered by Nouman Ali Khan. There were 48 data found by the researcher. The result of this research showed two points. First, seven types of requests appeared. They were (1)Suggestory Formulae 29\%, (2) Obligation Statement 21\%, (3) Query Preparatory 19\%, (4)Strong Hint 13\%, (5) Performatives 10\%, (6) Mild Hint 6\% and (7) Want Statement. The type commonly used was Suggestory Formulae then the least was Want Statement 2\%. Second, there found that each request uttered by the speaker always has signal words. The signal differentiates each requests base on the types. There are also two factors that influence the application of requests. Those are case and signal. The case influenced the speaker to utter the requests based on the context of lectures. While function influenced the requests types spoken by Nouman Ali in order to convey his intention. Finally, this research is advantageous for learning and applying requests strategies.
\end{abstract}

Keywords: Pragmatics, types of requests, quran tafseer

\begin{abstract}
Abstrak
Penelitian ini merupakan studi ilmu requests strategy pada Quran tafsir yang disampaikan oleh Nouman Ali Khan pada surah Al-Ihklas dan Al-Bayyinah menggunakan teori BlumKulka. Penelitian ini mengaplikasikan pendekatan pragmatik untuk menganalisis tipe dan pengaplikasian strategi-strategi request. Tujuan penelitian ini adalah; (1) untuk mengidentifikasi tipe request yang digunakan oleh Nouman Ali Khan pada pembelajaran Qur'an Tafsir Al-Ikhlas dan Al-Bayyinah dan (2) untuk menjelaskn pengaplikasian request yang disampaikan oleh Nouman Ali Khan dalam pembelajaran Qur'an Tafsir Al-Ikhlas dan Al-Bayyinah. Metode penelitian kualitatif dengan data berupa ujaran yang didapat dalam transkrip video pembelajaran Qur'an Tafsir Al-Ikhlas dan Al-Bayyinah. Hasil dari penelitian ini menjabarkan dua poin. Pertama, ditemukan tujuh tipe request yang diaplikasikan. Tipe yang ditemukan yakni; (1)Suggestory Formulae 29\%, (2) Obligation Statement 21\%, (3) Query Preparatory 19\%, (4)Strong Hint 13\%, (5) Performatives 10\%, (6) Mild Hint 6\% dan (7) Want Statement. Tipe yang paling sering digunakan adalah Suggestory Formulae dan
\end{abstract}


yang paling sedikit muncul adalah Want Statement. Kedua, setiap request yang digunakan dalam ujaran selalu memiliki kata kunci unsur yang membedakan tipe-tipe request. Ada dua factor yang mempengaruhi pengaplikasian requests yaitu kasus dan fungsi. Suatu kasus mempengaruhi pembicara dalam mengujarkan request yang didasarkan oleh konteks pembelajaran yang sedang dibahas. Sementara fungsi mempengaruhi tipe request yang diujarkan oleh Nouman Ali Khan yang bertujuan untuk menyampaikan tujuan isi surah. Kesimpulannya, penelitian ini bermanfaat bagi pembelajaran serta pengaplikasian request strategi.

Kata kunci: pragmatik, tipe request, quran tafsir

\section{INTRODUCTION}

In the process of learning language, the manner of how the message is told has an important role in making a communicative context. The Oxford philosopher, John L. Austin (as cited in Thomas, 1995) in his lecturer stated that was "able to demonstrate that people do not use language just to make statements about the world; they also use language to perform actions, which affect or change the world in some way."(p.44). In other words, language has an important rule to express people's intentions.

By the purpose to interact effectively and appropriately in a situation, a speaker needs to know the social rule that allow him to interpret and perform messages in a specific language. How language used in communication is called Pragmatics (Geoffrey Leech, 1983). Therefore it is important for people to know and understand the principle of language in some ways. There are two ways to convey messages; spoken and written. Both of them contain utterances. Searle (1969), stated that the utterances are included in speech act. The speech act is a unit of language used to express meaning. The utterance expresses an intention

According to Searle's classification, the speech act of a request is a directive act. Request is often performed in daily interactions. Trosborg (1995) states "A request is an illocutionary act whereby a speaker (requester) conveys to a hearer (requestee) that he/she wants the requestee to perform an act which is for benefit of the speaker".

There have been studies about speech acts. The first is by Marcia Macaulay entitled “Asking to ask: The Strategic Function of Indirect Requests for Information in Interview”. This research focused on how requests used by an interviewer to get information and opinions from a public figure. Another study was done by Wahidah from UNS (2014) entitled "Indirectness of Request in Barrack Obama's Speeches". It focused on how request used in term of speech and explained the context background and types of indirect requests. The next research divided requests in the pattern of lectures. Alemi Minoo \& Neda Khalarzadeh (2016) analyzed requests entitled "Pragmatic assessment of request speech act of Iranian EFL learners by non-native 
English speaking teachers". This research investigated how requests of teacher impact the students. Furthermore, this research combined the request effect with gender factors in influencing the hearer. Based on the previous studies, it is interesting that request speech act will be investigated further. Since the function of requests is to deliver the speaker's intention, there would be some advantageous obtained.

This study will find out the specific request types and function implied in Qur'an Tafseer. The chosen topic is requests which are used by Nouman Ali Khan in the lectures published in Qur'an Daily by Bayyinah TV entitled "Qur'an Tafseer of Qs. Al Bayyinah"and "Qur'an Tafseer of Qs. Al Ikhlas". There are three reasons of choosing this topic. Firstly, related to the theory that is used, Blum-Kulka emphasized requests types based on the politeness scale. The theory of this study is Request of Blum-kulka's Theory. The theory divided Request types based on the scale of directness. It means that it is closely related to politeness strategy. The theory of Blum-Kulka is useful related to polite behavior which becomes one of supporting element in public speaking. As stated by Blum-Kulka(1987:110), "The way to deliver request has a role in hearer's responds", this study emphasizes the request type that is used by an Islamic public speaker. This theory is also chosen because Islamic public speaking always considers politeness. Besides, Brown \& Levinson (1987:11), stated that "By making a request, the speaker impinges on the hearer's claim to freedom of action and freedom from imposition." Hence, the variety of direct and indirect ways for making requests seemingly available by the need to get respect responds. Secondly, looking from the side of the speaker, Nouman Ali Khan had appreciated as one of the 500 most influential Muslims in the world by the Royal Islamic Strategic Studies Centre of Jordan 2010. He is the founder of Islamic institution that actively translates and teaches Qur'an online and offline named Bayyinah. Thirdly, this study takes Qur'an tafseer of Surah Al-Ikhlas because this video has covered the intention of the speaker in delivering the message that explains the characteristic of God. This study also takes Qur'an tafseer of Surah Bayyinah because the surah explains the purpose of living it the world as the way to worshiping religion. Here are request utterances of Nouman Ali Khan lectures. For example:

So in a conflict as soon as the victory is guaranteed, it is important you to remember what is it that you are fighting about, to begin with what was the agenda of the conflict, what started this battle it wasn't about land, it wasn't about control, it wasn't about territory. (01/QAI/SF)

Nouman Ali Khan delivered his lecturer about the main thing to do after understanding the content of Surah Al-Ikhlas. The underlined utterance implies a request in type of Suggestion Statement. The suggestion is proven by the statements "it is important you to remember". It 
means that Nouman Ali has an intention to suggest the addressee to remember the case that he is talking about since conditions of religion in society right now are full of complicated purpose. Many people highlight their intention to bear down another religion in battle in order to get land, control, or glory. In that statement, Nouman Ali expressed the intention of doing battle and bear down another religion is actually to fulfill the religious command and spread Islam. Thus, it should be understood that all of the thing that people do should have sincerity that based on the sense of Surah Al-Ikhlas.

From the sample of analysis explanation above, the request utterances would be defined into types of requests and investigated as an indication of the speaker's intention. In addition, the utterances will be correlated with the background and environmental context in society to strengthen the intention

Therefore, this study will analyze the types of requests and the influence scale of requests used in the lectures of Nouman Ali Khan. This study is descriptive qualitative research with single case study. The data will be analyzed by using Pragmatics approach to find the meaning context with Blum-Kulka Theory.

\section{REVIEW OF RELATED LITERATURE}

The relevant theories used in this study are pragmatics. According to Wahidah (2001:6), he stated that "pragmatics studies the use of language in human communication as determined as the condition of the society". The central use of language is communication since communication in society occurs by means of language. In many forms of communication, people need a language to deliver their message. The part of pragmatics that applied by the speaker in ths case is Illocutionary Act. Illocutionary act deals with deeper meaning of utterance. It focuses more on the intention of speaker by saying the utterance. Illocution is also defined as the meaning intended by the speaker. The illocutionary act is analyzed based on context. It is about what is going in behind the text. Context is the background knowledge assumed to be shared by speaker and hearer. It contributes to hearer's interpretation (Leech, 1983). The meaning must be related to the context. It is used to find the illocutionary act. Then the theory of this study is requests strategy. The typology of request patterns has been listed by Soshana Blum-Kulka (Blum-Kulka, 1987). The scale is based on degrees of illocutionary. There are several types of requests. Those are; Mood Derivable, Performatives, Hedges Performatives, Obligation Statement, Want Statement, Suggestory Formulae, Query Preparatory, Strong Hint, and Mild Hint. 


\section{RESEARCH METHOD}

This study applied descriptive qualitative method. It aimed to identify the types of requests and explain the application of request used by Nouman Ali Khan lectures entitled "Qur'an Tafseer of Qs. Al Ikhlas"and" Qur'an Tafseer of Qs. Al Bayyinah. This study was based on Blum-Kulka Theory (1987). The data are the requests utterances in transcript of video "Qur'an Tafseer of Qs. Al Ikhlas"and" Qur'an Tafseer of Qs. Al Bayyinah" that were taken from www.nakcollection.com. There have been 36 qur'an tafseer lectures of Nouman Ali Khan which available in www.nakcollection.com. This study takes two of them since the lecture of Qur'an tafseer of Surah Al-Ikhlas has covered the intention of the lectures because this is the first lecture post and it contains some requests utterances with length 87 minutes. This study also takes Qur'an tafseer of Surah Bayyinah because the surah explains the purpose of living it the world as the way to worshiping religion, which means it would reflects some requests utterances which explained in 62 minutes.

\section{DISCUSSION}

There were nine types of requests that discussed. This research had 48 data containing request strategies. Suggestory Formulae became the strategy commonly used by Nouman Ali, which was 14 data. Mean while, Obligation Statement had 10 data, Query Preparatory had 9 data, Strong Hint had 6 data, Performatives had 5 data, Mild Hint had 3 data and Want Statement had 1 data. From the finding above, it can be concluded that no all types of requests strategies implied in Quran Tafseer Lecture of Nouman Ali Khan. The distribution of the data can be seen as the follow:

\section{Topics of data:}

QAI : refers to Qur;an Tafseer of Surah Al-Ikhlas

QAB : refers to Qur;an Tafseer of Surah Al-Bayyinah

\subsection{Data Finding of Requests analysis in Qur'an Tafseer of Surah Al-Ikhlas and Surah Al-} Bayyinah delivered by Nouman Ali Khan

\begin{tabular}{|l|l|l|l|l|l|}
\hline \multirow{2}{*}{ No } & Types of requests & \multicolumn{2}{|l|}{ Data } & \multirow{2}{*}{$\begin{array}{l}\text { data } \\
\text { findings }\end{array}$} & Percentage \\
\cline { 3 - 6 } & & QAI & QAB & \\
\hline 1 & Suggestory Formulae & 8 & 6 & 14 & $29 \%$ \\
\hline
\end{tabular}




\begin{tabular}{|l|l|l|l|l|l|}
2 & Obligation Statement & 4 & 6 & 10 & $21 \%$ \\
\hline 3 & Query Preparatory & 5 & 4 & 9 & $19 \%$ \\
\hline 4 & Strong Hint & 4 & 2 & 6 & $13 \%$ \\
\hline 5 & Performatives & 2 & 3 & 5 & $10 \%$ \\
\hline 6 & Mild Hint & 0 & 3 & 3 & $6 \%$ \\
\hline 7 & Want Statement & 1 & 0 & 1 & $2 \%$ \\
\hline \multicolumn{2}{|l|}{ TOTAL DATA } & $\mathbf{2 4}$ & $\mathbf{2 4}$ & $\mathbf{4 8}$ & $100 \%$ \\
\hline
\end{tabular}

\subsubsection{Suggestory Formulae}

According to Blum-Kulka Theory, Suggestory Formulae is the utterance which contains a suggestion to do something. The function of this requests type is to deliver request by stating the suggestion to the addressee.

\section{Datum 01/QAI/SF}

So in a conflict as soon as the victory is guaranteed, it is important you to remember what is it that you are fighting about, to begin with was the agenda of the conflict and what started this battle.

- Signal: Suggestion Statement; It is important to remember.

- Function: The utterance that the speaker says is directed to addressee to consider the case. The speaker intended to suggest the addresses to know the reason of QS.Al-Ikhlas appeared that it was started with the different opinion that cause a battle of social perspective at that time.

The case was about the main thing to do after understanding the content of Surah Al-Ikhlas. The underlined utterance implies a request in type of Suggestory Formulae. The suggestion is proven by the statements "it is important you to remember". It means that Nouman Ali had an intention to suggest the addressee to remember the case that he was talking about since the conditions of religion in society at that time are full of complicated purpose. In that statement, Nouman Ali expressed the intention of doing battle and bear down another religion is actually to fulfill the religious command and spread Islam. Thus, it should be understood that all of the thing that people do should have sincerity that based on the sense of Surah Al-Ikhlas.

\subsubsection{Obligation Statement}

Obligation statement is the utterances in which state the obligation of the hearer to carry out the 
act. It aims to direct the addressee to accomplish an act.

\section{Datum 02/QAI/OS}

Surah Al-Kafiroon and surah Al-Ikhlas should deserves a lot of attention, and it is interesting that from a literary point of view that the relationship becomes very obvious.

- Signal: Modal; Should.

- Function: the utterance that the speaker states is directed to the addressee to accomplish a conviction to Surah Al-Kafiroon and Surah Al-Ikhlas as they have a relation.

The case is about Surah Al-Kafiroon and Surah Al-Ikhlas that should have a special attention. He stated the request by using Obligation Statement. The underlined sentence implies that Nouman Ali intended to emphasize surah Al-Kafiroon and surah Al-Ikhlas as the significant subject to learn as those have the relationship of the fundamental belief in Islam. It is proven by the statement "Surah Al-Kafiroon and surah Al-Ikhlas should deserve a lot of attention" which means that convicting those Surahs is significant.

\subsubsection{Query Preparatory}

Query Preparatory is the utterances which contain reference to preparatory conditions (ability, willingness) as conventionalized in any specific language. The purpose of this type of requests is to state to the addressee to have an ability or willingness in considering an act.

\section{Datum 05/QAI/QP}

Then the sahabah would name it of course easiest one that you can appreciate it too.

- Signal: Modal that contains ability.

- Function: the utterance is stated to explain the name of surah Al-ikhlas that are able to be appreciated by the addressee.

In this case, Nouman Ali explained that the sahabah called Surah Al-Ikhlas with some different name. He requested the addressee to appreciate the name of surah Al-Ikhlas as the sahabah named. The underlined utterance belongs to request in type of Query Preparatory as the proof is the modal used which contains ability. Nouman Ali stated this by saying "you can appreciate it too" which means addresses may consider appreciating it through preparatory understanding the case.

\subsubsection{Strong Hint}

Strong Hint is the utterances which contains partial reference to object or element needed for the implementation of the act. It aims to deliver the request in indirect way by emphasizing the act to 
something that needs implementation from the addressee.

\section{Datum 19/QAI/SH}

There are several things to note here and we'll go through them one by one.

- Signal: element that needs implementation.

- Function: the utterance shows that the ayah needs implementation from the addresses that they should note the important message

In this case, Nouman Ali talked about the important ayah that consisted of important message. He requested the adresse by stating the element (the ayah that is talked in the lecture) to get special intention; "There are several things to note here and we'll go through them one by one." The purpose of this is to direct the addressee to take note and remember the ayah that was going to explained by Nouman Ali.

\subsubsection{Performatives}

Performatives is the utterances in which the illocutionary force is explicitly named. The purpose of this type of requests is to directly state the speaker's intention.

\section{Datum 07/QAI/P}

And now, look at the sign of the last day! One of the signs one is one of the things that happens before the last day comes.

- Signal: Performative word that contains force.

- Function: the utterance emphasize the force to addresses to look at their surrounding about the sign of the last day.

Nouman Ali would like to ask the addressee to look at the sign of last day. He stated his request in type of performative. He used imperative word to perform request asked by saying "And now, $\underline{\text { look }}$ at the sign of the last day!" which ends with exclamation mark. It means that Nouman Ali intended to force the hearer to establish a discerning about a case, in this statement is the sign of last day.

\subsubsection{Mild Hint}

Mild Hint is the utterances that make no reference to the request proper (or any of its elements) but are interpretable as a request by context. It aims to deliver the request I indirect way that addressee can catch the intention without stated in detail by the speaker.

\section{Datum 06/QAB/MH}

Some of it rubs off on them ad so when you look at them on the outside you going to good person, or you wouldn't think that there is any good on the inside but actually there is. 
- Signal: A statement that is interpretated as request.

- Function: the utterance is directed to the addresses as the intention of the speaker to convince them to have a positive thought.

In this case, Nouman Ali talked about how to appraise someone. He requested the addressee in term of Mild Hint. It is proven by the underlined words that he stated. He directed the addressee to have a positive thought by stating the explanation "you wouldn't think that there is any good on the inside but actually there is."

\section{Datum 10/QAB/MH}

\subsubsection{Want Statement}

Want Statement is the utterances in which state the speaker's desire that the hearer carries out the act. The purpose of this type of request is to deliver the request directly and politely.

\section{Datum 20/QAI/WS}

But then what I wanted to bring to your attention is something that is not often overlooked when we study lam yalidu wa lam yulad.

- Signal: Want Statement

- Function: the utterance is directed to the addresses in order to make them hear what speaker says.

Nouman Ali explained about the meaning of an ayah that needs attention. He requested the addressee to pay attention on a sentence by using request strategy of Want Statement. It was proven by the direct statement that he used, that Nouman Ali wanted to get the attention of the hearer. He told his desire by stating "But then what_I wanted to bring to your attention is something that is not often overlooked when we study lam yalidu wa lam yulad." The utterance was directed to the addresses in order to make them act as what speaker says.

From the explanation above, all of the research revealed that style of request strategy in delivering public speaking as the way to state the speaker's intention. Therefore, this study supports the previous research by giving further explanation of request.

\section{CONCLUSION}

Referring to the analysis of Requests Strategy delivered by Nouman Ali Khan in Qur'an Tafseer Lecture of Qs.Al-Ikhlas and Qs.Al-Bayyinah, the findings showed that seven strategies of requests are employed by Nouman Ali Khan. The researcher found that there are 48 data on Qur'an Tafseer Lecture of Qs.Al-Ikhlas and Qs.Al-Bayyinah contained requests utterances. The 
type commonly used by Nouman Ali Khan was Suggestory Formulae and no all types of requests strategies implied in Quran Tafseer Lecture of Nouman Ali Khan.

This research applied the request theory of Blum-Kulka in analyzing Qur'an Tafseer Lecture of Qs.Al-Ikhlas and Qs.Al-Bayyinah delivered by Nouman Ali Khan. There found that each request uttered by the speaker always has signal words. The signal differentiates each requests base on the types. There are also two factors that influence the application of requests. Those are Case and Function. The case influences the speaker to utter the requests based on the context of lectures. While function influence the requests types spoken by Nouman Ali in order to convey his intention.

\section{REFERENCES}

Alemi Minoo \& Neda Khalarzadeh. 2016. Pragmatic assessment of request speech act of Iranian EFL learners by non-native English speaking teachers. Urmia. Urmia University Iran.

Austin, J. 1962. How to Do Things with Words. London: Oxford University

Blum-Kulka, Soshana. 1987. Indirection and Politeness in requests: same or different? Journal of Pragmatics 11:131-146

Blum-Kulka, S., House, J. \& Kasper, G. (Eds.) 1989. Cross-cultural pragmatics: Requests and apologies. Norwood, NJ: Ablex.

Cohen, A. D. \& Olshtain, E. 1987. The production of speech acts by EFL learners. TESOL Quartely, 27(1): 33-35.

Flores, E. 2011. The pragmatics of requests and apologies: developmental patterns of mexican students. Mexico

Hassall, T. 2003. Requests by Australian learners of Indonesian. Journal of Pragmatics, 35: 1903-1928.

Leech,G. 1983. Principle of Pragmatics. London. Longman.

Levinson, S. 1983. Pragma tics. Cambridge: Cambridge University Press.

Olshtain, E. and A. Cohen 1984. 'Apology: a speech act set' in N. Wolfson and J. Elliott (eds.). TESOL and Sociolinguistic Research. Rowley, MA: Newbury House.

Macaulay, Marcia. 2001. Asking to ask: The Strategic Function of Indirect Requests for Information in Interview. Belfast. International Pragmatics Association

Mira ,A. 2008. Pragmatics and Grammar. Yerusalem. Linguistic Department Tel Aviv University. 
Searle, J. 1991. "Indirect Speech Act" in Pragmatics A Reader. Ed Steven Davis . New York: Oxford University Press

Santosa, R. 2014. Metode Penelitian Kualitatif Kebahasaan. UNS. Unpublished thesis retrieved from https://digilib.uns.ac.id/dokumen/search

Takahashi, S. 1996. Pragmatic transferability. Studies in Second Language Acquisition, 18: 189223.

Thomas, J. 1983. 'Cross-cultural pragmatic failure'. Applied Linguistics 4/2:91-112.

Trosborg, A. 1995. Interlanguage pragmatics: Requests, complaints and apologies. Berlin, NY: Mounton de Gruyter.

Wahidah, M. 2014. Indirectness of Request in Barrack Obama's Speeches (Pragmatics Approach).UNS. Solo. Unpublished thesis retrieved from https://digilib.uns.ac.id/dokumen/search Wed, $23^{\text {th }}$ December 2016 at 10.00 p.m

Yule, G. 2010. Pragmatics. Bristol: Oxford University Press.

https://digilib.uns.ac.id/dokumen/search Wed, $23^{\text {th }}$ December 2016 at 10.00 p.m

www.nakcollection.com Sat, $12^{\text {th }}$ January 2017 at 08.00 a.m

www.bayyinah.com Sun, $14^{\text {th }}$ January 2017 at 11.0 a.m

http://www.ebook777.com/pragmatics-requests-apologies-developmental-patterns-mexican-

students/ Sun, $14^{\text {th }}$ January 2017 at 12.30 p.m

http://muslimmatters.org/2011/04/28/top-ten-islamic-lectures-of-all-time-videos/ Monday, 22 $2^{\text {th }}$ January 2017 at 10.00 p.m 